ISSN: 1305-578X

Journal of Language and Linguistic Studies, 15(1), 307-325; 2019

\title{
Cognitive processing of second language idiom comprehension: A comparative
}

APA Citation: \author{
study \\ Burcu Aydin a * iD \\ ${ }^{a}$ Adnan Menderes University, Aydin 09100, Turkey
}

Aydin, B., (2019). Cognitive processing of second language idiom comprehension: a comparative study. Journal of Language and Linguistic Studies, 15(1), 307-325.

Submission Date:21/09/2018

Acceptance Date:07/01/2019

\begin{abstract}
This study examines the cognitive processes underlying the comprehension of L2 idiomatic expressions by using two different visual instructional techniques - pictorial representation of literal meanings versus pictorial representation of figurative meanings of each idiomatic expression - considering two settings (EFL vs. ESL), two different types of idioms (opaque vs. transparent) and two different proficiency levels (intermediate vs. advanced). The treatment included common pedagogical practices that use Dual Coding Theory as two different visual techniques with verbal support to teach different types of idioms. $67 \mathrm{ESL}$ and $63 \mathrm{EFL}$ learners attended the study. Idiom Comprehension Test was used before and after the treatment. Results of repeated-measure ANOVA based on pre- and post-test comparisons revealed that the comprehension of L2 idioms differed with respect to the learning setting, instructional technique, and idiom type. Nevertheless, proficiency level did not seem to have any effect on comprehension outcomes of any group. The results showed that in the ESL setting, the figurative technique was more successful than literal technique; while in EFL setting the literal technique resulted in better scores compared to figurative technique. ESL learners were better at learning idioms with opaque meanings than learners in EFL settings whereas EFL students were better at learning idioms with transparent meanings. The results of this study support the view of the Dual Idiom Representation Model stating that ESL learners activate their existing idiom entry and they comprehend figuratively whereas EFL learners must decompose idioms.
\end{abstract}

(C) 2019 JLLS and the Authors - Published by JLLS.

Keywords: L2 Idiom comprehension; metaphorical language, cognitive processing; L2 learning setting; instructional technique

\section{Introduction}

Metaphoric lexical items, which have figurative meanings in discourse, play an important role in efficient communication by enriching meaning. In the field of second language (L2) learning, the acquisition of these figurative formulaic sequences is an essential part of linguistic competence (Boers et al., 2009; Cooper, 1999; Liu, 2008; Zyzik, 2011) since L2 fluency depends on accurately interpreting and using metaphorical lexical items. However, L2 learners' speech and writing suggest significant struggles in producing figurative words in meaningful ways (Howarth, 1998) such that their knowledge

\footnotetext{
* Corresponding author. Tel.: +90-5055250204

E-mail address: burcu.aydin@adu.edu.tr
} 
of L2 metaphorical lexical items is not equal to their knowledge of overall L2 vocabulary (Steinel et al., 2007).

The most common means of figurative language used in everyday conversation is idioms (Erman \& Warren, 2000). Idioms have been defined as conventional multi-word units that are semantically opaque and structurally fixed and whose semantic interpretation cannot be derived from the meaning of its individual parts (Cacciari \& Tabossi, 1988; Kovacs, 2016; Langlotz, 2006). In the past the teaching of idioms was generally neglected because of their unpredictable arbitrary meaning - it was believed that they could not be taught in any systematic way and students were by and large forced to memorize them (Boers et. al. 2004). Although there is little research on the L2 learning of idioms, in recent years, however, more studies have investigated how we can better address the acquisition of idioms, which are an important part of knowing a language, and how they should be systematically merged into L2 curricula (Zyzik, 2011).

Today, most of the cognitive linguists agree that idiom comprehension demands a different course of processing other than that of literal language. Researchers investigate which topographical regions of the brain are active during idiom comprehension, to resolve the ongoing dispute on hemispheric specialization in figurative language processing. It is reported that left lateralized centers are vital for idiom comprehension (Aydin et. al. 2017, Mitchell et. al. 2016, Yang et. al. 2010, Fogliata et al. 2007, Papagno et. al. 2006, Cacciari et al. 2006).

Current research into the comprehension of figurative language has aimed to understand the underlying cognitive processes of L2 idiom comprehension and provide effective instructional techniques. For instance, some studies have aimed to understand how L2 learners construct the metaphorical meanings of idioms - do they deduce the meaning by combining the literal meanings of the constituent words of the idiom or rather do they use a figurative interpretation of individual items? Some researchers have reported that literal meanings of idioms gain priority during L2 idiom comprehension in L2 instructed learning environments (Cieślicka, 2006; Abel, 2003; Papagno \& Caporali, 2007; Samburskiy, 2015). On the other hand, others have found that figurative meanings of L2 idioms have a facilitative effect on L2 learning (Vasilijevic, 2013; Gluckberg, 2001; Van de Voort \& Vonk, 1995).

The current study expands the research on L2 idiom comprehension by examining the cognitive processes underlying the comprehension of L2 idiomatic expressions. The use of two different instructional techniques, one using pictorial representation of literal and one using pictorial representation of figurative meanings of L2 idioms in two different settings (EFL versus ESL) with two different idiom types (opaque versus transparent) and at two different proficiency levels (intermediate versus advanced) were investigated.

\subsection{Literature review}

Idioms, as multi-word expressions with at least one element with a figurative meaning, are different with respect to a variety of features: literality, compositionality, and idiomaticity (Cacciari et al., 2006; Nippold \& Rudzinski, 1993). Literality refers to the degree to which an idiom has a potential literal interpretation, and compositionality, whether the constituent words can be mapped directly on their idiomatic referents (Titone \& Connine, 1999). The spectrum of idiomaticity denotes whether the meaning can be easily derived from its constituent parts. The spectrum of idiomaticity categorizes idioms according to transparency or opacity, in a continuum from transparent to opaque. The key query in idiomaticity is how far the idiomatic meaning of an idiom is from its literal counterparts (Chitra, 1996). The figurative meaning in a transparent idiom may be deducted from the literal meanings of its component words. Therefore, in most cases interpretation of transparent idioms are not puzzling as both 
components have a direct meaning, but the combination attains a figurative sense. In an opaque idiom, there is no connection among the literal and figurative meanings and it should be comprehended as a whole lexical unit since it is impossible to deduce the genuine meaning of the idiom from the meanings of its components. Researchers consider transparent idioms easier to understand than opaque idioms (Cacciari \& Levorato, 1998; Gibbs, 1991; Nippold \& Duthie, 2003).

\subsubsection{First Language Idiom Processing and Acquisition Models}

Metaphorical language is more difficult to understand than literal speech because metaphorical language is patterned and related to a literal sense; thus, idiom comprehension requires a different processing pathway from literal language comprehension (Aydin et al. 2017). There are two main psychological models that have attempted to explain the cognitive process underlying the comprehension of idiomatic expressions: the traditional view and compositional view. According to the traditional view of idiom representation and processing, idioms are considered to be non-compositional and unanalysable semantic features processed non-compositionally, or as fixed lexical units. Earlier researchers with this view first asked whether the literal or the figurative meaning is retrieved during idiom comprehension and secondly if both meanings are retrieved, what the order will be. Three studies which tested these questions constitute the oldest idiom processing hypotheses: The Idiom List Hypothesis (Bobrow and Bell, 1973), the Lexical Representation Hypothesis (Swinney and Cutler, 1979), and the Direct Access Hypothesis (Gibbs, 1980). These hypotheses stated that the meaning of an idiom is stored in a distinct mental idiom list (Weinreich, 1969). According to Bobrow and Bell (1973), the literal meanings of idioms are processed initially, and after its refusal, the idiomatic meaning is comprehended. Swinney and Cutler (1979) suggested simultaneous activation of both the literal and the figurative meanings. Gibbs (1980) suggested that idiom's figurative meaning is triggered without the literal meaning being processed initially.

On the other hand, according to the compositional view, idioms are considered semantically analysable structures that can be processed compositionally. Cacciari and Tabossi (1988) developed a hypothesis called the Configuration Model in which they claimed that the literal meaning of the constituents of an idiom is initiated and triggered during comprehension. The Configuration Model suggests that the idiomatic configuration is identified through the activation of the idiomatic key. Gibbs and colleagues (Gibbs \& Nayak, 1989; Gibbs, Nayak \& Cutting, 1989) developed the Idiom Decomposition Hypothesis, which refers to the speaker's expectations about how the constituents' meanings assist in the figurative meaning of the whole idiom (Gibbs \& Nayak, 1989). This hypothesis claims that as decomposability is an influencing factor on comprehension or representation, an idiom's degree of decomposability can be controlled. A decomposable idiom is an idiom whose constituents contribute to the figurative meaning. The Hybrid Model of Idiom Comprehension (Titone and Connine, 1999) includes aspects from both the traditional and compositional views, investigating whether the idiomatic or the literal meaning is initially processed during idiom comprehension. It claims that both meanings (literal and the figurative) are activated during processing.

Finally, figurative language acquisition in the first language (L1) is considered to be somewhat different from standard L1 acquisition approaches. Two hypotheses (Acquisition via Exposure Hypothesis and Global Elaboration Hypothesis) sought to explain the underlying system of idiom acquisition (Ezell \& Goldstein, 1991; Levorato\& Cacciari, 1995). According to Acquisition via Exposure Hypothesis, idioms are acquired by being exposed to daily discourse conversation. Consequently, familiar idioms are supposed to be acquired with ease compared to unfamiliar ones. The findings of Levorato and Cacciari (1992) opposed this hypothesis, suggesting that the degree of familiarity of idioms did not have an effect on idiom comprehension but has an effect on production. According to the Global Elaboration Hypothesis (Levorato \& Cacciari, 1995), idiom comprehension is expected to be developed parallel with the cognitive development of the child; in other words, it follows 
the same pathway as general linguistic competence, with no particular procedure needed to comprehend and produce figurative language. On the other hand, it is known that not all the idioms are acquired in the same way as opaque ones may follow a rote manner.

\subsubsection{L2 Idiom Processing and Learning Models}

In the field of L2 learning and teaching, there has been an attempt to develop cognitive approaches to idiomatic language, assuming that L2 idiom processing is different as it requires both literal and figurative processing of constituents (Boers, 2004; Grant, 2007; Szczepaniak \& Lew, 2011).

The Dual Idiom Representation Model, developed by Abel (2003), is a psycholinguistic model which compensates for factors neglected by other models. The model suggests two levels of representation a lexical and a conceptual one. These dual representations coexist at the lexical level. The model claims that if an idiom entry exists at the lexical level, the conceptual level is not activated. Only after the rejection of the literal meaning at the lexical level, the idiomatic meaning at the conceptual level is retrieved. The model also assumes that non-decomposable idioms require an idiom entry, whereas decomposable idioms can be represented via constituent entries and can additionally develop an idiom entry. On the condition that decomposable idioms do not have idiom entry at the lexical level, conceptual representations are activated during comprehension. According to Abel, apart from an idiom's degree of decomposability, the frequency of an idiom identifies the development of an idiom entry. Empirical studies of this model also support the decomposability of idioms with L1 and L2 speakers of English, integrating the representation of idioms in both $\mathrm{L} 1$ and $\mathrm{L} 2$ lexicons.

In the application of cognitive processes to instruction, Dual Coding Theory (Sternberg, 2003) suggests that using both visual and verbal inputs simultaneously may facilitate the recall of newly acquired idioms. Steinel et al. (2007) evaluated two idiom characteristics, imageability and transparency, emphasizing the impact of dual coding in idiom comprehension. They stated that imageability effects performance since in low imageable idioms receptive learning was inefficient.

Comprehension of idioms may also be affected by the context of learning. Researchers have found that generally, there are differences for learners in second language contexts - where the dominant language in the community is the target language - compared to those in foreign language contexts, where the majority of exposure to English is restricted to the classroom (Dörnyei, 2009; Ellis, 2008; Huebner, 1995; Plonsky, 2011; Sasaki, 2007; Segalowitz \& Freed, 2004; Wu \& Zhang, 2017). In second language settings, students may have increased exposure to the target language and opportunities to hear more authentic, realistic discourse than in foreign language settings, as well as increased motivation to learn and more chances to develop effective learning processes and strategies. In addition, Gibbs (2011) found that when learners experience metaphorical language in isolation, it takes them longer to understand than literal language, but when encountered in realistic discourse contexts, figurative speech can be understood as quickly as literal speech, which can be found in second language learning contexts.

\subsection{Research questions}

This study investigates the cognitive processes underlying the comprehension of L2 idiomatic expressions by evaluating whether the use of literal versus figurative meanings have an effect on student learning in two different settings - ESL versus EFL. It aims to identify which of two instructional techniques - pictorial representation of literal meanings of each idiomatic expression versus pictorial representation of figurative meanings of each idiomatic expression - is more effective for learning with the hope to reduce comprehension challenges L2 learners encounter when they learn idioms. No research, to my knowledge, has explored this topic by making comparative evaluations in two different L2 learning settings with regards to two different visual techniques with verbal support and two different 
types of idioms by two different proficiency levels. This study addresses the following research questions:

(1) Are there differences in comprehension of L2 idioms with respect to L2 learning setting (ESL vs. EFL), technique (literal vs. figurative), and proficiency level (advanced vs. intermediate)?

(2) Does comprehension of idioms differ when a pictorial representation of literal meaning technique vs. a pictorial representation of figurative meaning technique is used in the two settings (ESL vs. EFL)?

(3) Do differences in students' comprehension of idioms vary by idiom type (opaque vs. transparent) across the two settings (ESL vs. EFL)?

(4) Do differences in students' comprehension of idioms vary by type (opaque vs. transparent) and proficiency level (advanced vs. intermediate) in the two settings (ESL vs. EFL)?

\section{Method}

This quantitative study explores the cognitive processes of L2 idiom learning, considering the learning setting, the idiom type, and learners' proficiency level. It involves an experiment on the teaching of L2 idioms in two different ways (literal vs. pictorial), using pre- and post-test results to compare the learning outcomes. Below, details about methodological design including the participants, the instruments, and data collection and analyses procedures are presented.

\subsection{Participants}

To address the research questions around possible differences in learning outcomes by settings, the study was conducted in two different countries: students who were studying English as a Second Language (ESL) in the U.S.A., and students who were studying English as a Foreign Language (EFL) in Turkey.

For the EFL setting, a group of university students in an English Language Education Department in Turkey participated in the study. The ESL setting participants included university students in English Second Language Department at a private university in Eastern U.S.A. and a group of English language learners in a government-run intermediate centre in the same city. At the time of data collection, all EFL participants were learning English for nearly 10 years since middle school. Their ages ranged between 21 and 24 years. The duration of exposure to English in a week in school varied between 25 and 30 hours and outside the school varied between 15 and 20 hours. For ESL setting, all the participants had been living in the U.S.A. more than nine months at the time of data collection. Their age range was 22 to 28. At the time of data collection, the duration of exposure to English in a week in school was between 25 and 30 hours, while for outside the school this amount was much higher, varying between 40 and 60 hours a week.

The total number of ESL and EFL participants who attended this experiment were 67 and 63 respectively. The visual technique that involved the pictorial use of literal meanings of each idiomatic expression with verbal support was applied to 35 ESL participants and 30 EFL participants. As such, the visual technique that utilized the pictorial use of figurative meanings of each idiomatic expression with verbal support was applied to 32 ESL participants and 33 EFL participants. The proficiency levels (intermediate vs. advanced) of participants were determined based on the institution's proficiency test administrated by the faculty experts in foreign language education. 


\subsection{Instrument( $s)$}

This quantitative study involved an experiment that included a Participant Background Survey and an Idiom Comprehension Test. The University Institutional Review Board (IRB) approval was secured before any data collection took place. First, participants were asked to sign the Consent Form prepared by the researcher and approved by the IRB. Second, participants were given the Background Survey that asked questions about differences in learning outcomes between students in ESL and EFL settings, as well as some background and demographic questions, including age, gender, ethnicity, native language, amount of exposure and interaction with authentic language input, home language use, and education level. Third, the Idiom Comprehension Test which was adapted from Tran (2013) was applied. This test was used twice as pre- and post-tests; first, to assess the participants' initial level of metaphorical competence - knowledge of idioms - before the treatment, and second, to evaluate the effect of the imagery technique with verbal support on idiom comprehension for EFL versus ESL learners after the treatment. The test consisted of 20 most frequently used idioms which were selected from the Oxford Dictionary of English Idioms (Ayto, 2010) and double checked from the findings of the corpus-based study done by Liu (2003) under the supervision of three faculty members of ELT Department in USA. The faculty members were native speakers of English. To evaluate the effect of idiom type on comprehension, 10 opaque and 10 transparent idioms were used. The test included three parts: participants were asked to (1) complete the missing parts of idioms according to their given meaning, (2) match the idiom with its correct meaning, and (3) find the correct idiom for given situations. The test contained 20 comprehension questions. The test took 30 to 40 minutes to complete.

\subsection{Data collection procedures}

The participants were requested to complete the Participant Background Survey and also they were asked to complete the Idiom Comprehension Test before and after the treatment. The treatment included common pedagogical practices that use Dual Coding Theory as two different visual techniques (pictorial representation of literal meanings vs. pictorial representation of figurative meanings) with verbal support (definition of the idiom and the sentence in which the idiom is used) to teach different types (opaque vs. transparent) of idioms. The treatments for ESL and EFL groups were delivered by the same researcher, either in a whole-class setting or with students individually during their regular academic studies. The aim of the research was clearly explained to the participants. Data collection process took about six months.

\subsection{Data analysis}

This study involved several comparisons of pre-and post-test scores across the ESL vs. EFL, visual vs. figurative technique, and advanced vs. intermediate proficiency levels in a $2 \times 2 \times 2$ factorial design repeated measures ANOVA. The pre-and post-treatment scores of opaque and transparent idiom types were defined as dependent variables. English learning setting (ESL vs. EFL), proficiency level (intermediate vs. advanced) and visual technique (pictorial representation of literal meaning vs. pictorial representation of the figurative meaning of idiomatic expressions) were the between-subjects factors. As the research questions explored possible changes in mean scores due to the experiment, a 3-way repeated measures ANOVA was performed. Sphericity was tested with Mauchly's test. Statistical significance was assumed for $\mathrm{p}<0.05$. One-way ANOVA was used to evaluate the level of metaphorical competence of the groups by comparing the pretest scores.

As the post-hoc test was not available in a $2 \times 2 \times 2$ factorial design, the English learning setting (ESL vs. EFL) and the visual technique (Literal=LIT vs. Figurative=FIG) groups were re-coded in four groups (ESL-LIT, ESL-FIG, EFL-LIT, and EFL-FIG). This facilitated post-hoc comparisons of the significant 
difference among the mentioned factors that were revealed in analyses of data for research question one. One-way repeated measures ANOVA was performed with the Tukey HSD to evaluate the post-hoc interaction.

\section{Results}

In this section, to address each research question, first, the descriptive statistics are presented. Table 1 demonstrates pre-test and post-tests mean scores and standard deviations for each group. Pre-test scores of the participants in ESL and EFL groups were compared and no significant difference was found in pretest scores; $F(1,129)=0.675$, $p=0.413$ in transparent idioms and $F(1,129)=2.702, p=0.103$ in opaque idioms.

Table 1. Descriptive Statistics of the groups, means and standard deviations of Pre- and Post-test scores of Transparent and Opaque Idioms. ESL: English as a Second Language, EFL: English as a Foreign Language, SD: Standard Deviation

\begin{tabular}{|c|c|c|c|c|c|c|c|c|c|c|c|}
\hline & \multirow[b]{3}{*}{$\begin{array}{c}\text { Visual } \\
\text { Technique }\end{array}$} & \multirow[b]{3}{*}{$\begin{array}{l}\text { Proficiency } \\
\text { Level }\end{array}$} & \multicolumn{4}{|c|}{ Transparent Idioms } & \multicolumn{4}{|c|}{ Opaque Idioms } & \multirow[b]{3}{*}{$\mathrm{N}$} \\
\hline & & & \multicolumn{2}{|c|}{ Pre-test } & \multicolumn{2}{|c|}{ Post-test } & \multicolumn{2}{|c|}{ Pre-test } & \multicolumn{2}{|c|}{ Post-test } & \\
\hline & & & Mean & SD & Mean & SD & Mean & SD & Mean & SD & \\
\hline \multirow{9}{*}{ ESL } & \multirow{3}{*}{ Figurative } & Intermediate & 1.06 & .80 & 9.06 & 1.11 & 1.17 & .92 & 9.33 & .84 & 18 \\
\hline & & Advanced & 1.36 & .74 & 8.93 & 1.07 & 1.14 & 1.17 & 8.79 & 1.31 & 14 \\
\hline & & Total & 1.19 & .78 & 9.00 & 1.08 & 1.16 & 1.02 & 9.09 & 1.09 & 32 \\
\hline & \multirow{3}{*}{ Literal } & Intermediate & 1.00 & .63 & 5.95 & 1.20 & 1.00 & .63 & 6.43 & .98 & 21 \\
\hline & & Advanced & 1.00 & .39 & 5.21 & 1.05 & 1.36 & 1.01 & 5.93 & 1.14 & 14 \\
\hline & & Total & 1.00 & .54 & 5.66 & 1.19 & 1.14 & .81 & 6.23 & 1.06 & 35 \\
\hline & \multirow{3}{*}{ Total } & Intermediate & 1.03 & .71 & 7.38 & 1.94 & 1.08 & .77 & 7.77 & 1.72 & 39 \\
\hline & & Advanced & 1.18 & .61 & 7.07 & 2.16 & 1.25 & 1.08 & 7.36 & 1.89 & 28 \\
\hline & & Total & 1.09 & .67 & 7.25 & 2.03 & 1.15 & .91 & 7.60 & 1.79 & 67 \\
\hline \multirow{9}{*}{ EFL } & \multirow{3}{*}{ Figurative } & Intermediate & 1.19 & .40 & 7.00 & 1.37 & .75 & .58 & 4.75 & 1.00 & 16 \\
\hline & & Advanced & 1.00 & .35 & 7.59 & 1.23 & .71 & .69 & 4.24 & .75 & 17 \\
\hline & & Total & 1.09 & .38 & 7.30 & 1.31 & .73 & .63 & 4.48 & .91 & 33 \\
\hline & \multirow{3}{*}{ Literal } & Intermediate & 1.33 & .49 & 9.87 & .35 & 1.13 & .99 & 8.67 & .98 & 15 \\
\hline & & Advanced & 1.20 & .68 & 9.87 & .35 & 1.07 & .80 & 8.33 & 1.11 & 15 \\
\hline & & Total & 1.27 & .58 & 9.87 & .35 & 1.10 & .88 & 8.50 & 1.04 & 30 \\
\hline & \multirow{3}{*}{ Total } & Intermediate & 1.26 & .44 & 8.39 & 1.76 & .94 & .81 & 6.65 & 2.21 & 31 \\
\hline & & Advanced & 1.09 & .53 & 8.66 & 1.47 & .88 & .75 & 6.16 & 2.27 & 32 \\
\hline & & Total & 1.17 & .49 & 8.52 & 1.62 & .90 & .78 & 6.40 & 2.24 & 63 \\
\hline Total & Figurative & Intermediate & 1.12 & .64 & 8.09 & 1.60 & .97 & .80 & 7.18 & 2.49 & 34 \\
\hline
\end{tabular}




\begin{tabular}{|c|c|c|c|c|c|c|c|c|c|c|}
\hline & Advanced & 1.16 & .58 & 8.19 & 1.33 & .90 & .94 & 6.29 & 2.52 & 31 \\
\hline & Total & 1.14 & .61 & 8.14 & 1.47 & .94 & .86 & 6.75 & 2.53 & 65 \\
\hline \multirow{3}{*}{ Literal } & Intermediate & 1.14 & .59 & 7.58 & 2.17 & 1.06 & .79 & 7.36 & 1.48 & 36 \\
\hline & Advanced & 1.10 & .56 & 7.62 & 2.48 & 1.21 & .90 & 7.17 & 1.65 & 29 \\
\hline & Total & 1.12 & .57 & 7.60 & 2.30 & 1.12 & .84 & 7.28 & 1.55 & 65 \\
\hline \multirow{3}{*}{ Total } & Intermediate & 1.13 & .61 & 7.83 & 1.92 & 1.01 & .79 & 7.27 & 2.02 & 70 \\
\hline & Advanced & 1.13 & .57 & 7.92 & 1.98 & 1.05 & .93 & 6.72 & 2.17 & 60 \\
\hline & Total & 1.13 & .59 & 7.87 & 1.94 & 1.03 & .85 & 7.02 & 2.10 & 130 \\
\hline
\end{tabular}

\subsection{Overall Analyses by Setting, Technique, and Proficiency Level}

To determine if there were differences in comprehension of L2 idioms with respect to L2 learning setting (ESL vs. EFL), technique (literal vs. figurative), and proficiency level (advanced vs. intermediate), a repeated measures $2 \times 2 \times 2$ factorial ANOVA model was constructed.

Results revealed that there was a significant difference between pre-test and post-test scores of the ESL and EFL groups and visual technique regarding the opaque idiom scores, $F(1,122)=203.86$, MSE: $1.03, \mathrm{p}<0.001$ (Table 2). There were also significant differences within groups regarding the techniques, including the ESL-Figurative technique group (Pre-test Mean=1.16 \pm 1.02 and Post-tests Mean= 9.09 \pm 1.09 ); ESL-Literal technique group (Pre-test Mean= $1.14 \pm 0.81$ and Post-tests Mean= $6.23 \pm 1.06$ ); EFL-Figurative technique group (Pre-test Mean= $0.73 \pm 0.63$ and Post-tests Mean= $4.48 \pm 0.91$ ) and EFL-Literal technique group (Pre-test Mean=1.10 \pm 0.88 and Post-tests Mean= $8.50 \pm 1.04$ ). For subgroup descriptive statistics, please see Table 1.

Table 1 Repeated measures 3-way ANOVA of opaque idiom test scores as the dependent variable and withinsubjects variables respectively, English learning setting, Proficiency Level and Visual Technique. ESL: English as a Second Language, EFL: English as a Foreign Language, VT: Visual Technique, PL: Proficiency Level $(p<0.05) *$ : Statistically significant difference

\begin{tabular}{cccccc}
\hline & \multicolumn{2}{c}{ Tests of Between-Subjects Effects } & & & \\
Type III Sum of & Squares & df & Mean & F & Sig. \\
\hline Source & 4191.20 & 1.00 & 4191.20 & 4084.57 & $<.001$ \\
& 30.23 & 1.00 & 30.23 & 29.46 & $<.001^{*}$ \\
Intercept & 9.26 & 1.00 & 9.26 & 9.02 & $.003^{*}$ \\
ESL/EFL & 2.80 & 1.00 & 2.80 & 2.72 & .101 \\
Pisual Technique (VT) & 209.18 & 1.00 & 209.18 & 203.86 & $<.001^{*}$ \\
Proficiency Level (PL) & .06 & 1.00 & .06 & .06 & .810 \\
ESL/EFL* VT & .34 & 1.00 & .34 & .34 & .563 \\
ESL/EFL * PL & .07 & 1.00 & .07 & .07 & .791 \\
VT * PL & 125.18 & 122.00 & 1.03 & & \\
ESL/EFL * PL * VT & & & & & \\
Error & & & & &
\end{tabular}


Table 2 Repeated measures 3-way ANOVA of transparent idiom test scores as the dependent variable and within-subjects variables respectively, English learning setting, Proficiency Level and Visual Technique. ESL: English as a Second Language, EFL: English as a Foreign Language, VT: Visual Technique, PL: Proficiency Level $(\mathrm{p}<0.05) *$ : Statistically significant difference

\begin{tabular}{ccccccc}
\hline & \multicolumn{2}{c}{ Tests of Between-Subjects Effects } & & & \\
Type III Sum of & df & Mean Square & F & Sig. \\
\hline Source & Squares & & & & \\
& 5264.37 & 1.00 & 5264.37 & 6766.50 & $<.001$ \\
EStercept & 29.98 & 1.00 & 29.98 & 38.53 & $<.001 *$ \\
Visual Technique (VT) & 3.02 & 1.00 & 3.02 & 3.88 & .051 \\
Proficiency Level (PL) & .09 & 1.00 & .09 & .11 & .738 \\
ESL/EFL* VT & 161.60 & 1.00 & 161.60 & 207.72 & $<.001 *$ \\
ESL/EFL * PL & .69 & 1.00 & .69 & .89 & .348 \\
VT * PL & 2.09 & 1.00 & 2.09 & 2.69 & .104 \\
ESL/EFL * PL * VT & .14 & 1.00 & .14 & .18 & .669 \\
Error & 94.92 & 122.00 & .78 & & \\
\hline
\end{tabular}

Also, there was a significant between-group difference in pre-test and post-test scores of the ESL and EFL groups and visual technique regarding the transparent idiom scores $\mathrm{F}(1,122)=207.72$, MSE: $0.78, \mathrm{p}<0.001$; with the group means calculated as, the ESL-Figurative technique group $(\mathrm{N}=32)$ (Pretest Mean= $1.19 \pm 0.78$ and Post-tests Mean=9.00 \pm 1.08$)$; ESL-Literal technique group ( $=35)$ (Pretest Mean $=1.00 \pm 0.54$ and Post-tests Mean= $5.66 \pm 1.19)$; EFL-Figurative technique group $(\mathrm{N}=33)$ (Pre-test Mean $=1.09 \pm 0.38$ and Post-test Mean=7.30 \pm 1.31$)$ and EFL-Literal technique group $(\mathrm{N}=30)$ (Pre-test Mean $=1.27 \pm 0.58$ and Post-test Mean $=9.87 \pm 0.35$ ) in pre-test and post-test transparent idiom scores (Table 1). (Table 3).

These results revealed that both in terms of opaque and transparent idioms, both L2 learning setting and visual techniques had an effect on comprehension of idioms; however, there was no statistically significant difference among the proficiency levels in both opaque and transparent idioms ( $\mathrm{p}=0.101$ for opaque idioms $\mathrm{p}=0.738$ for transparent idioms). (Tables 2 and 3 ).

\subsection{Analyses by ESL vs EFL Setting and Technique}

To determine if the two visual techniques (pictorial representation of literal meanings vs. pictorial representation of figurative meanings of each idiomatic expression) differ in L2 idiom comprehension, post-hoc tests were performed. However, as the repeated measures $2 \times 2 \times 2$ factorial ANOVA did not allow for post-hoc tests, the ESL vs. EFL and Figurative vs. Literal groups were re-coded into 4 groups. One-way repeated measures ANOVA with post-hoc Tukey HSD revealed the following results. 
Table-4 Descriptive Statistics of the learning setting and visual technique groups, means and standard deviations of Pre- and Post-test scores of Transparent and Opaque Idioms in factorial design of the Setting and The Visual technique groups. ESL: English as a Second Language, EFL: English as a Foreign Language, FIG: Figurative,

LIT: Literal, SD: Standard Deviation

\begin{tabular}{|c|c|c|c|c|c|c|c|c|c|}
\hline & \multicolumn{4}{|c|}{ Transparent Idioms } & \multicolumn{4}{|c|}{ Opaque Idioms } & \multirow[b]{3}{*}{$\mathrm{N}$} \\
\hline & \multicolumn{2}{|c|}{ Pre-test } & \multicolumn{2}{|c|}{ Post-test } & \multicolumn{2}{|c|}{ Pre-test } & \multicolumn{2}{|c|}{ Post-test } & \\
\hline & Mean & SD & Mean & SD & Mean & $\mathrm{SD}$ & Mean & SD & \\
\hline ESL-FIG & 1.19 & 0.78 & 9.00 & 1.08 & 1.16 & 1.02 & 9.09 & 1.09 & 32 \\
\hline ESL-LIT & 1.00 & 0.54 & 5.66 & 1.19 & 1.14 & 0.81 & 6.23 & 1.06 & 35 \\
\hline EFL-FIG & 1.09 & 0.38 & 7.30 & 1.31 & 0.73 & 0.63 & 4.48 & 0.91 & 33 \\
\hline EFL-LIT & 1.27 & 0.58 & 9.87 & 0.35 & 1.10 & 0.88 & 8.50 & 1.04 & 30 \\
\hline
\end{tabular}

In opaque idiom scores, there was a significant difference among the groups determined via one-way repeated measures ANOVA, $\mathrm{F}(1,126)=83.19$, MSE: 1.02, $\mathrm{p}<0.001$. A Tukey HSD post-hoc test revealed that the difference in comprehension scores between the ESL-FIG group (Pre-test Mean $=1.16$ \pm 1.02 and Post-test Mean $=9.09 \pm 1.09$ ) and the EFL-LIT group (Pre-test Mean=1.10 \pm 0.88 and Posttest Mean $=8.50 \pm 1.04$ ) was not significant $(\mathrm{p}=0.28)$. The Tukey HSD test also showed that, ESL-FIG and the EFL-LIT groups had higher scores compared to both ESL-LIT (Pre-test Mean $=1.14 \pm 0.81$ and Post-test Mean $=6.23 \pm 1.06$ with $p<0.01$ ) and EFL-FIG (Pre-test Mean=0.73 \pm 0.63 and Post-test Mean $=4.48 \pm 0.91$ with $\mathrm{p}<0.01$ ) groups (Tables 4, 5 and 6).

Table-5 One-way Repeated measures ANOVA of opaque idiom pre-test and post-test scores as the dependent variable and within-subjects variables, English learning setting and Visual Technique. ESL: English as a Second Language $(\mathrm{p}<0.05) *$ : Statistically significant difference

\begin{tabular}{cccccc}
\hline & \multicolumn{2}{c}{ Tests of Between-Subjects Effects } & & \\
Source & Type III Sum of Squares & df & Mean & F & Sig. \\
\hline $\begin{array}{c}\text { Intercept } \\
\text { Factorial }\end{array}$ & 4260.30 & 1.00 & 4260.30 & 4179.26 & $<.001$ \\
Groups & 254.42 & 3.00 & 84.81 & 83.19 & $<.001^{*}$ \\
Error & 128.44 & 126.00 & 1.02 & & \\
\hline
\end{tabular}


Table-6 Tukey HSD post-hoc analysis of factorial groups in opaque idioms sample. ESL: English as a Second Language, EFL: English as a Foreign Language, FIG: Figurative, LIT: Literal (p<0.05) *: Statistically significant difference

\begin{tabular}{|c|c|c|c|c|c|c|}
\hline & & \multirow{2}{*}{$\begin{array}{c}\text { Mean Difference } \\
(\mathrm{I}-\mathrm{J})\end{array}$} & \multirow[t]{2}{*}{ Std. Error } & \multirow[t]{2}{*}{ Sig } & \multicolumn{2}{|c|}{$95 \%$ Confidence Interval } \\
\hline & & & & & Lower Bound & Upper Bound \\
\hline \multirow[t]{3}{*}{ ESL-FIG } & ESL-LIT & 1.44 & .17 & .00 & .98 & 1.89 \\
\hline & EFL-LIT & .33 & .18 & .28 & -.15 & .80 \\
\hline & EFL-FIG & 2.52 & .18 & .00 & 2.06 & 2.98 \\
\hline \multirow[t]{3}{*}{ ESL-LIT } & ESL-FIG & -1.44 & .17 & .00 & -1.89 & -.98 \\
\hline & EFL-LIT & -1.11 & .18 & .00 & -1.58 & -.65 \\
\hline & EFL-FIG & 1.08 & .17 & .00 & .63 & 1.53 \\
\hline \multirow[t]{3}{*}{ EFL-LIT } & ESL-FIG & -.33 & .18 & .28 & -.80 & .15 \\
\hline & ESL-LIT & 1.11 & .18 & .00 & .65 & 1.58 \\
\hline & EFL-FIG & 2.19 & .18 & .00 & 1.73 & 2.66 \\
\hline \multirow[t]{3}{*}{ EFL-FIG } & ESL-FIG & -2.52 & .18 & .00 & -2.98 & -2.06 \\
\hline & ESL-LIT & -1.08 & .17 & .00 & -1.53 & -.63 \\
\hline & EFL-LIT & -2.19 & .18 & .00 & -2.66 & -1.73 \\
\hline
\end{tabular}

As for the transparent idiom scores, there was a significant difference among the groups determined via one-way repeated measures ANOVA $F(1,126)=82.65$, MSE: $0.78, \mathrm{p}<0.001$. A Tukey-HSD post-hoc test revealed that the idiom comprehension score in EFL-LIT (Pre-test Mean $=1.27 \pm 0.58$ and Post-test Mean $=9.87 \pm 0.35$ with $\mathrm{p}<0.01$ ) was the highest followed by ESL-FIG (Pre-test Mean $=1.19 \pm 0.78$ and Post-test Mean $=9.00 \pm 1.08$ with $p=0.01$ ), EFL-FIG (Pre-test Mean $=1.13 \pm 0.59$ and Post-test Mean= $7.30 \pm 1.31$ with $\mathrm{p}<0.01$ ) and ESL-LIT (Pre-test Mean= $1.00 \pm 0.54$ and Post-test Mean= $5.66 \pm 1.19$ with $\mathrm{p}<0.01$ ), consecutively (Tables 4,7 , and 8 ).

Table-7 One-way Repeated measures ANOVA of transparent idiom pre-test and post-test scores as the dependent variable and within-subjects variables, English learning setting and Visual Technique. ESL: English as a Second Language $(\mathrm{p}<0.05) *$ : Statistically significant difference

\begin{tabular}{cccccc}
\hline \multirow{2}{*}{ Source } & \multicolumn{2}{c}{ Tests of Between-Subjects Effects } & Mean & F & Sig. \\
\hline Intercept & Type III Sum of Squares & df & Square & & \\
Factorial & 5357.77 & 1.00 & 5357.77 & 6884.83 & $<.001$ \\
Groups & 192.95 & 3.00 & 64.32 & 82.65 & $<.001^{*}$ \\
Error & 98.05 & 126.00 & 0.78 & & \\
\hline
\end{tabular}


Table-8 Tukey HSD post-hoc analysis of factorial groups in transparent idioms sample. ESL: English as a Second Language, EFL: English as a Foreign Language, FIG: Figurative, LIT: Literal ( $<<0.05)$ *: Statistically significant difference.

\begin{tabular}{|c|c|c|c|c|c|c|}
\hline & & \multirow{2}{*}{$\begin{array}{c}\text { Mean Difference } \\
\text { (I-J) }\end{array}$} & \multirow[t]{2}{*}{ Std. Error } & \multirow[t]{2}{*}{ Sig } & \multicolumn{2}{|c|}{ 95\% Confidence Interval } \\
\hline & & & & & Lower Bound & Upper Bound \\
\hline \multirow[t]{3}{*}{ ESL-FIG } & ESL-LIT & 1.77 & .15 & .00 & 1.37 & 2.16 \\
\hline & EFL-LIT & -.47 & .16 & .02 & -.89 & -.06 \\
\hline & EFL-FIG & .90 & .15 & .00 & .49 & 1.30 \\
\hline \multirow[t]{3}{*}{ ESL-LIT } & ESL-FIG & -1.77 & .15 & .00 & -2.16 & -1.37 \\
\hline & EFL-LIT & -2.24 & .16 & .00 & -2.64 & -1.83 \\
\hline & EFL-FIG & -.87 & .15 & .00 & -1.26 & -.47 \\
\hline \multirow[t]{3}{*}{ EFL-LIT } & ESL-FIG & .47 & .16 & .02 & .06 & .89 \\
\hline & ESL-LIT & 2.24 & .16 & .00 & 1.83 & 2.64 \\
\hline & EFL-FIG & 1.37 & .16 & .00 & .96 & 1.78 \\
\hline \multirow[t]{3}{*}{ EFL-FIG } & ESL-FIG & -.90 & .15 & .00 & -1.30 & -.49 \\
\hline & ESL-LIT & .87 & .15 & .00 & .47 & 1.26 \\
\hline & EFL-LIT & -1.37 & .16 & .00 & -1.78 & -.96 \\
\hline
\end{tabular}

Taken together, these results showed that in both idiom types, the figurative technique (pictorial representation of figurative meanings) was more successful than literal technique (pictorial representation of literal meanings) in ESL setting; however, literal technique resulted in better scores than figurative technique in EFL setting.

\subsection{Analyses by ESL vs. EFL Setting and Idiom Type}

The third research question addressed if there were differences between L2 setting groups (ESL vs EFL) in terms of two different idiom types (opaque vs. transparent). The results obtained from the $2 \times 2 \times 2$ repeated measures factorial ANOVA revealed the following differences.

These findings indicated that in opaque idioms there was a significant difference within the ESL group (N=67) (Pre-test Mean=1.15 \pm 0.91 and Post-test Mean= $7.60 \pm 1.79)$ and EFL group $(\mathrm{N}=63)$ (Pre-test Mean $=0.90 \pm 0.78$ and Post-test Mean=6.40 \pm 2.24 ) in pre-test and post-test opaque idiom scores, $\mathrm{F}(1,122)=29.46$, MSE: 1.03, $\mathrm{p}<0.001$ (Tables 1 and 2).

In transparent idioms, there was a significant difference within the ESL group (Pre-test Mean $=1.09$ \pm 0.67 and Post-test Mean= $7.25 \pm 2.03$ ) and EFL group (Pre-test Mean=1.17 \pm 0.49 and Post-test Mean $=8.52 \pm 1.62)$ in pre-test and post-test transparent idiom scores, $F(1,122)=38.53$, MSE: $0.78, \mathrm{p}<$ 0.001 (Tables 1 and 3).

Results revealed that in opaque idioms, the ESL group produced significantly better learning outcomes compared to the EFL group. In contrast, in transparent idioms, the EFL group had significantly better learning outcomes compared to the ESL group.

\subsection{Analyses by ESL vs. EFL Setting and Proficiency Level}

The fourth research question addressed if there were differences in the comprehension of idioms between students in ESL versus EFL settings due to students' proficiency levels. Results obtained from the $2 \times 2 \times 2$ repeated measures factorial ANOVA revealed the differences outlined below. 
There was no significant difference within the ESL-Advanced group ( $\mathrm{N}=28)$ (Pre-test Mean= $1.25 \pm$ 1.08 and Post-test Mean= $7.36 \pm 1.89$ ); ESL-Intermediate group (N=39) (Pre-test Mean=1.08 \pm 0.77 and Post-test Mean= $7.77 \pm 1.72$ ); EFL-Advanced group ( $\mathrm{N}=32$ ) (Pre-test Mean $=0.88 \pm 0.75$ and Posttest Mean $=6.16 \pm 2.27$ ) and EFL-Intermediate group ( $\mathrm{N}=31)$ (Pre-test Mean= $0.94 \pm 0.81$ and Post-test Mean $=6.65 \pm 2.21$ ) in pre-test and post-test opaque idiom scores, $\mathrm{F}(1,122)=0.06$, MSE: $1.00, \mathrm{p}=0.810$ (Tables 1 and 2).

In addition, there was no significant difference within the ESL-Advanced group ( $\mathrm{N}=28)$ (Pre-test Mean $=1.18 \pm 0.61$ and Post-test Mean= 7.07 \pm 2.16$)$; ESL-Intermediate group $(\mathrm{N}=39)$ (Pre-test Mean= $1.03 \pm 0.71$ and Post-test Mean= $7.38 \pm 1.94)$; EFL-Advanced group $(\mathrm{N}=32)$ (Pre-test Mean= $1.09 \pm$ 0.53 and Post-test Mean $=8.66 \pm 1.47$ ) and EFL-Intermediate group $(\mathrm{N}=31)$ (Pre-test Mean= $1.26 \pm 0.44$ and Post-test Mean= $8.39 \pm 1.76)$ in pre-test and post-test transparent idiom scores, $F(1,122)=0.89$, MSE: $0.78,+p=0.348$ (Tables 1 and 3). These results revealed that the proficiency level did not have an effect on learning outcomes in any setting.

\section{Discussion}

As there is an ongoing debate in the literature whether idioms' figurative or literal meanings gain priority in L2 idiom comprehension, this study aimed to investigate two different techniques in the instruction of L2 idioms to understand the cognitive processes of L2 idiom comprehension. By using materials and techniques that contrasted pictorial representations of literal versus figurative meanings, it was possible to compare learners' outcomes in comprehension of idioms based on idiomaticity. Also the possible effect of setting (EFL vs. ESL) and proficiency level (intermediate versus advanced) was accounted. With the support of Dual Coding Theory, two different visual techniques were used with additional verbal support. In the related literature, no research has investigated this topic by making comparative evaluations in two different L2 learning settings by using two different visual techniques with verbal support.

The findings of the study suggest that L2 idiom comprehension differs according to the learning setting and technique used (RQ 1). Detailed statistical evaluation for further analysis revealed the technique differences in different settings which were pursued in RQ2. The results showed that in the ESL setting, the figurative technique was more successful than literal technique; while in EFL setting the literal technique resulted in better scores compared to figurative technique, in both idiom types. It is suggested that ESL learners different from EFL learners processed idiomatic expressions compositionally which reports the influence of setting in comprehension. In terms of setting, in the ESL setting, learners' outcomes were better when the instructional technique with the figurative representation of idiomatic meanings was used. In addition, ESL learners were better at learning idioms with opaque meanings than learners in EFL settings. In contrast, in the EFL setting, learners' outcomes were better when the instructional technique with a literal representation of idiomatic meanings was used, and EFL students were better at learning idioms with transparent meanings than learners in ESL settings (RQ3).

Liontas (2002) studied the influence of context in comprehension of L2 idioms in EFL setting and found that text supporting has a beneficial effect on comprehension and reported that L2 learners process literal and idiomatic meanings independently and they interpret idiomatic sense after the literal understanding has been excluded. This study supports the idea that the context in which the L2 idioms are presented is critical in comprehension. However, in this study, both contextual support and pictorial representation technique with the support of Dual Coding Theory were used. What is more, different from Liontas (2002) who studied L2 idiom comprehension only in EFL setting, this study evaluated and 
compared L2 idiom comprehension in both ESL and EFL settings. Samburskiy (2015) reported that in helping learners acquire the figurative meanings of idioms, an imagery technique that presents a pictorial representation of literal meanings versus figurative meanings of idiomatic expressions has been found to be effective. The results of this study are partially in consistency with Samburskiy's findings reporting that pictorial representation of literal meanings of idioms is an effective technique in EFL setting for comprehension of transparent idioms.

Vasiljević (2013) studied the effect of learner-generated illustrations of the literal meaning of the given idioms combined with verbal definitions compared to verbal definitions only. Their results indicated that pictorial support of the literal meaning facilitated retention of idiom form but not the figurative meaning. However, the results of this study indicated that pictorial representation of the literal meanings of L2 transparent idioms has an effect on learning in the EFL setting. Cieślicka (2006) reported that literal meaning of idiomatic expressions gains priority during L2 idiom comprehension as literal meanings of idioms are more salient than their figurative meanings, similarly, the results of this study support this finding reporting that in EFL setting literal meanings of idioms gained priority in comprehension. Papagno and Caporali (2007) reported that the literal meaning of idiomatic expressions may have a triggering effect on the comprehension of their figurative sense. The results of this study are in consistency with their findings as literal meanings of idioms in this study had a facilitative effect in comprehension of transparent idioms in EFL setting. Boers et al. (2004) reported that L2 learners process and recall figurative idioms by etymological elaboration technique which enables raising their awareness of the literal origins of both transparent and opaque idioms. Also, they stated the beneficial effect of Dual Coding Theory in retention of L2 figurative idioms as it stores verbal information as a mental image and provides an extra pathway for recall. The results of this study partially in accordance with Boers et. al. (2004) as in ESL setting, neither mapping the literal meaning of transparent idioms nor opaque idioms enable learners to figure out their idiomatic meaning on the other hand in EFL setting pictorial representation of literal meanings of transparent idioms have a facilitative effect on comprehension. Furthermore, it is believed that the Dual Coding Theory has an effect on comprehension of metaphoric language as it both provides processing verbal and visual input simultaneously.

The results of this study also indicated that different proficiency levels do not have any effect on learning outcomes (RQ4), which contradicts research by Matlock and Heredia (2002), which suggested that L2 learner's proficiency level in the language determines the strategy of processing of L2 literal versus figurative meanings.

The findings of this study also support previous research that second language learning settings do indeed have an effect on L2 learning (Ellis, 2008; Gibbs, 2011; Plonsky, 2011; Sasaki, 2007), such that second language environments may provide a better language learning environment than foreign language ones.

Taking into account the idiomaticity (level of transparency of an idiom) in this study, learners in second language settings performed better in the comprehension of items when presented with input that is more figurative (opaque), non-compositional, and less clearly interpretable, as compared to the learners in foreign language contexts who comprehended idioms that were more literal (transparent, compositional, and more interpretable) better. This finding ties into the idea that in the ESL context, learners have increased exposure to authentic language and may have developed strategies which lead to comprehension processes that access figurative meanings directly (Abel, 2003; Titone \& Connine, 1999) without accessing an idiom's literal meaning, which is in opposition to findings from Liontas (2002). In contrast, since EFL learners mostly have experienced classroom settings more focused on form, translation strategies, and behaviourist techniques, students may have developed comprehension processes that favour these strategies. Therefore, learners were more successful in learning idioms that 
were more literal in meaning, processed by accessing their individual lexical units and then recomposing their meaning.

In comparing idiom decomposability between L1 and L2 speakers of English, Abel (2003) claimed that L2 speakers evaluated opaque idioms as decomposable and attributed meaning to individual constituents. The results of this study support the view of Dual Idiom Representation Model by (Abel 2003) that the two levels (conceptual and lexical) occur at the same time but the frequency and decomposability determine the route to be processed. Abel reported that the more frequently the idiom occurs as an idiom configuration, the more there is the development of an idiom entry. For this reason, the results of this study suggest that EFL learners have to decompose idioms and force the activation of their constituent entries whereas ESL learners do not have to consider the constituent meaning of idioms because they activate their existing idiom entry.

\section{Conclusions}

This study examined the processes underlying the comprehension of L2 idiomatic expressions by investigating different instructional techniques involving two idiom types in separate learning settings with learners varying in proficiency levels. This study adds to research on idiom comprehension by comparing L2 learners in second language and foreign language settings, emphasizing the importance that setting and instruction technique can have on L2 learning. Findings of this study contribute to a growing body of research investigating L2 figurative language processing, supporting Dual Idiom Representation Model that posits representation of idioms at both lexical and conceptual levels at the same time; of which one of the levels will be preferred according to the existing idiom entry. The results of the study also offer modifications to educational strategies conforming to cognitive processing of figurative language aiming the ultimate learning outcomes. In EFL setting, in order to activate learners' idiom entry and help them comprehend opaque idioms better figurative technique with the support of Dual Idiom Representation Model should be used.

As with any experimental study attempting to understand cognitive processes in language learning, this study also has limitations. The number of idioms in the study is limited, as required by the experimental task. Future studies could use the same techniques while using a variety of different idioms to further validate these findings.

\section{Acknowledgements}

This study was funded by The Scientific and Technological Research Council of Turkey (TUBITTAK) via 2219 - Abroad Postdoctoral Research Scholarship Program in 2016 1st term [grant number 1059B191601008].

\section{References}

Abel, B. (2003). English idioms in the first and second language lexicon: A dual representation approach. Second Language Research, 19(4), 329-58.

Aydin, B., Barin, M., Yagiz, O. (2017). Comprehension of Idioms in Turkish Aphasic Participants. J Psycholinguist Research, 46(6):1485-1507.

Ayto, J. (Ed.). (2010). Oxford dictionary of English idioms. Third Edition. New York: Oxford University Press. 
Boers, F., Piriz, A.H.J., Stengers, H., Eyckmans, J. (2009). Does pictorial elucidation foster recollection of idioms? Language Teaching Research, 13(4), 367-382.

Boers, F. (2004). Expanding learners' vocabulary through metaphor awareness: What Expansion, what Learners, what vocabulary? In M. Achard, S. Niemeler (Eds.), Cognitive linguistics, second language acquisition, and foreign language teaching (pp. 211-232). Berlin: Mouton de Gruyter.

Boers, F., Demecheleer, M., \& Eyckmans, J. (2004). Etymological elaboration as a strategy for learning figurative idioms. In P. Bogaards \& B. Laufer (Eds.), Vocabulary in a second language: Selection, acquisition, and testing. (pp. 53-78). Amsterdam: John Benjamins.

Bobrow, S. A., \& Bell, S. M. (1973). On catching on to idiomatic expressions. Memory \& Cognition, 1(3), 343-346.

Cacciari, C., \& Levorato, M. C. (1998). The effect of semantic analyzability of idioms in metalinguistic tasks. Metaphor and Symbol, 13(3), 159-177.

Cacciari, C., Reati, F., Colombo, M. R., Padovani, R., Rizzo, S., \& Papagno, C. (2006). The Comprehension of ambiguous idioms in aphasic patients. Neuropsychologia, 44(8), 1305-1314.

Cacciari, C., \& Tabossi, P. (1988). The comprehension of idioms. Journal of Memory and Language, 27(6), 668-683.

Chitra, F. (1996). Idioms and idiomaticity. Oxford: Oxford University Press.

Cieslicka, A. (2006). Literal salience in on-line processing of idiomatic expressions by second language learners. Second Language Research, 22(2), 115-144.

Cooper, T. (1999). Processing of idioms by L2 learners of English. TESOL Quarterly, 33, 233-262.

Dörnyei, Z. (2009). Individual differences: Interplay of learner characteristics and learning environment. Language Learning, 59, 230-248.

Ellis, R. (2008). The study of second language acquisition (2nd ed.). Oxford: Oxford University Press.

Erman, B., \& Warren, B. (2000). The idiom principle and the open choice principle. Text, 20(1), 29-62.

Ezell, H. K., \& Goldstein, H. (1991). Comparison of idiom comprehension of normal children and children with mental retardation. Journal of Speech, Language, and Hearing Research, 34(4), 812819.

Fogliata, A., Rizzo, S., Reati, F., Miniussi, C., Oliveri, M., \& Papagno, C. (2007). The Time Course of Idiom Processing. Neuropsychologia, 45(14), 3215-3222.

Gibbs Jr, R. W., \& Nayak, N. P. (1989). Psycholinguistic studies on the syntactic behavior of idioms. Cognitive Psychology, 21(1), 100-138.

Gibbs, R. W. (1980). Spilling the beans on understanding and memory for idioms in conversation. Memory \& Cognition, 8(2), 149-156.

Gibbs, R. W. (1991). Semantic analyzability in children's understanding of idioms. Journal of Speech, Language, and Hearing Research, 34(3), 613-620.

Gibbs Jr, R. W. (2011). Evaluating conceptual metaphor theory. Discourse Processes, 48(8), 529-562.

Gibbs Jr, R. W., Nayak, N. P., \& Cutting, C. (1989). How to kick the bucket and not decompose: Analyzability and idiom processing. Journal of Memory and Language, 28(5), 576-593.

Giora, R. (1997). Understanding figurative and literal language: the graded salience hypothesis. Cognitive Linguistics, 8, 183-206. 
Grant, L. E. (2007). In a manner of speaking: Assessing frequent spoken figurative idioms to assist ESL/EFL teachers. System, 35(2), 169-181.

Howarth, P. (1998). Phraseology and second language proficiency. Applied Linguistics, 19, 24-44.

Huebner, T. (1995). The effects of overseas language programs. In B. F. Freed (Ed.), Second language acquisition in a study abroad context (pp. 171-194). Philadelphia: John Benjamins.

Kovács, G. (2016). About the definition, classification, and translation strategies of idioms. Acta Universitatis Sapientiae, Philologica, 8(3), pp. 85-101.

Langlotz, A. (2006). Idiomatic creativity: A cognitive-linguistic model of idiom-representation and idiom-variation in English. Amsterdam: John Benjamins Publishing Company.

Levorato, M. C., \& Cacciari, C. (1995). The effects of different tasks on the comprehension and production of idioms in children. Journal of Experimental Child Psychology, 60(2), 261-283.

Levorato, M. C., \& Cacciari, C. (1992). Children's comprehension and production of idioms: the role of context and familiarity. Journal of Child Language, 19(2), 415-433.

Liontas, J. (2002). Context and idiom understanding in second languages. EUROSLA yearbook, 2(1), $155-185$.

Liu, D. (2003). The most frequently used spoken American English idioms: A corpus analysis and its implications. TESOL Quarterly, 37 (4), 671-700.

Liu, D. (2008). Idioms: Description, comprehension, acquisition, and pedagogy. New York: Routledge.

Matlock, T., \& Heredia, R.R. (2002). Understanding phrasal verbs in monolinguals and bilinguals. In R.R. Heredia \& J. Altarriba (Eds.), Bilingual sentence processing (pp. 251-274). Amsterdam: Elsevier.

Mitchell, R. L., Vidaki, K., \& Lavidor, M. (2016). The role of left and right dorsolateral prefrontal cortex in semantic processing: A transcranial direct current stimulation study. Neuropsychologia, 91, 480489.

Nippold, M. A., \& Duthie, J. K. (2003). Mental imagery and idiom comprehension: A comparison of school-age children and adults. Journal of Speech, Language \& Hearing Research, 46(4), 788-799.

Nippold, M. A., \& Rudzinski, M. (1993). Familiarity and transparency in idiom explanation: A developmental study of children and adolescents. Journal of Speech, Language, and Hearing Research, 36(4), 728-737.

Papagno, C., Curti, R., Rizzo, S., Crippa, F., \& Colombo, M. R. (2006). Is the Right Hemisphere Involved in Idiom Comprehension? A Neuropsychological Study. Neuropsychology, 20(5), 598.

Papagno, C., \& Caporali, A. (2007). Testing idiom comprehension in aphasic patients: The effects of task and idiom type. Brain and Language, 100(2), 208-220.

Plonsky, L. (2011). The effectiveness of second language strategy instruction: A meta - analysis. Language learning, 61(4), 993-1038.

Samburskiy, D. (2015). The effect of a dual coding elucidation technique on idiom comprehension in ESL and EFL learners. Doctoral dissertation, State University of New York, Albany.

Sasaki, M. (2007). Effects of study - abroad experiences on EFL writers: A multiple - data analysis. The Modern Language Journal, 91(4), 602-620. 
Segalowitz, N., \& Freed, B. F. (2004). Context, contact, and cognition in oral fluency acquisition: Learning Spanish in at home and study abroad contexts. Studies in Second Language Acquisition, 26(2), 173-199.

Steinel, M.P., Hulstijn, J.H., Steinel, W. (2007). Second language idiom learning in a paired -associate Paradigm. Studies in Second Language Acquisition, 29, 449-484.

Sternberg, R. J. (2003). Cognitive theory (3rd ed.). Belmont, CA: Thomson Wadsworth.

Szczepaniak, R., \& Lew, R. (2011). The role of imagery in dictionaries of idioms. Applied Linguistics, 32(3), 323-347.

Swinney, D. A., \& Cutler, A. (1979). The access and processing of idiomatic expressions. Journal of Verbal Learning and Verbal Behavior, 18(5), 523-534.

Titone, D. A., \& Connine, C. M. (1999). On the compositional and noncompositional nature of idiomatic expressions. Journal of Pragmatics, 31(12), 1655-1674.

Tran, H. (2013). Figurative idiomatic competence: An analysis of EFL learners in Vietnam. Language Education in Asia, 4(1), 23-38.

Van de Voort, M.E.C., \& Vonk, W. (1995). You don't die immediately when you kick an empty bucket: A processing view on semantic and syntactic characteristics of idioms. In M. Everaert, E. van der Linden, A. Schenk, \& R. Schreuder (Eds), Idioms: Structural and psychological perspectives (pp. 283-299). Hillsdale, NJ: Lawrence Erlbaum Associates.

Vasiljević, Z. (2013). Effects of learner-generated illustrations on comprehension and recall of L2 idioms. ELTA Journals, 1(1), 24-46.

Yang, F. G., Fuller, J., Khodaparast, N., \& Krawczyk, D. C. (2010). Figurative Language Processing After Traumatic Brain Injury in Adults: A Preliminary Study. Neuropsychologia, 48(7), 1923-1929.

Weinreich, U. (1969). Problems in the analysis of idioms. In J. Puhvel (Ed.), Substance and structure of language (pp. 23-81). Berkeley: University of California Press.

Wu, H., \& Zhang, L. J. (2017). Effects of different language environments on Chinese graduate students' perceptions of English writing and their writing performance. System, 65, 164-173.

Zyzik, E. (2011). Second language idiom learning: The effects of lexical knowledge and pedagogical sequencing. Language Teaching Research, 15(4), 413-433. 


\section{İkinci dildeki deyimsel ifadelerin kavranmasının bilişsel işlemlenmesi: Karşılaştırmalı bir çalışma}

\section{$\ddot{O} \mathbf{z}$}

Çalışma, ikinci dilde deyim kavrama sürecindeki bilişsel süreçleri araştırmaktadır. Çalışmada iki farklı görsel teknik- her bir deyimin sözlüksel anlamının resimlenerek gösterilmesi veya her bir deyimin mecazi anlamının resimlenerek gösterilmesi- kullanılmıştır. Bu farklı teknikler iki farklı ortamda-İngilizcenin ikinci dil olarak veya İngilizcenin yabancı dil olarak öğretildiği ortamlarda- ve iki farklı deyim türü (örtük ve açık anlamlı) kullanılarak, iki farklı dil yetkinlik düzeyinde (orta düzey ve gelişmiş düzey) uygulanmıştır. Çalışmanın uygulama kısmında iki farklı görsel teknik, İkili Kodlama Teorisine dayanarak hem görsel hem de sözel uyaranlar kullanılarak uygulanmıştır. İngilizceyi ikinci dil olarak öğrenen 67 bireyle, İngilizceyi yabancı dil olarak öğrenen 63 birey çalışmaya katılmıştır. Deyim Kavrama Testi hem uygulama öncesi hem de uygulama sonrası kullanılmıştır. Çalışmada kullanılan tekrarlayan örneklerde varyans analizi sonuçları ikinci dildeki deyim kavrama sürecinin öğrenme ortamına, öğrenme yöntemine ve deyim türüne göre değişiklik gösterdiğidir. Bunun aksine öğrencilerin dil yeterlilik seviyelerinin deyimleri kavramada herhangi bir etki teşkil etmediği saptanmıştır. Çalışmanın sonuçları İngilizceyi ikinci dil olarak öğrenen bireylerin deyimlerin mecazi anlamlarının resmedilerek öğretildiği teknikte daha başarılı olduklarını gösterirken İngilizceyi yabancı dil olarak öğrenen bireylerin deyimlerin sözlüksel anlamlarının resmedilerek öğretildiği teknikte daha başarılı olduğunu göstermiştir. İngilizceyi ikinci dil olarak öğrenen bireyler örtük deyimleri öğrenmede daha başarılı iken İngilizceyi yabancı dil olarak öğrenen bireyler açık anlamlı deyimleri öğrenmede daha başarılı bulunmuştur. Çalışmanın sonuçları İkili Deyim Temsil Modelini desteklerken İngilizceyi ikinci dil olarak öğrenen bireylerin deyim öğrenme sürecinde var olan deyim depolarını aktive ettiklerini ve deyimleri mecazi anlamlarıyla kavradıklarını gösterirken diğer bir taraftan İngilizceyi yabancı dil olarak öğrenen bireylerin de deyimleri ayrıştırarak, her bir parçayı ayrı ayrı anlamlandırarak öğrendiklerini ortaya çıkarmıştır.

Anahtar sözcükler: İkinci Dilde Deyim Anlamlandırma; Mecazi Dilin Bilişsel İşlemlenmesi; İkinci Dil Öğrenme Ortamı; Öğretim Tekniği

\section{AUTHOR BIODATA}

Burcu Aydın is an assistant professor in English Language Teaching Department at Adnan Menderes University. She received her MA degree in Linguistics from Dokuz Eylül University and her PhD degree in Linguistics from Atatürk University. She is interested in psycholinguistics and neurolinguistics. She teaches Linguistics, Applied Linguistics, First and Second Language Acquisition, Language Teaching Methods and Approaches courses. She has published articles in various refereed international and national journals and presented papers in national and international conferences. 